\title{
ĐặC ĐIỂM LÂM SÀNG VÀ ĐIỀU TRỊ Sốc SốT XUẤT HUYẾT DENGUE Ở TRẺ EM TẠI BỆNH VIỆN NHI ĐỒNG 1 TỪ 2019-2020
}

\section{TÓM TẮT}

Đă̆t vấn đề -Mục tiêu nghiên cứu: sốt xuất huyết dengue là bệnh có tỷ lệ mắc cao, là 1 trong các vấn đề y tế quan trọng ở Miền Nam, Việt Nam. Nghiên cứu này xác định đặc điểm dịch tễ, lâm sàng, cận lâm sàng và các biêp pháp điêu trị sốc sốt xuất huyết dengue ở trẻ em nhập điều trị sớm tại bệnh viện Nhi Đồng 1. Đối tương và phương pháp nghiên cứu: Mô tả hàng loạt ca, tiến cứu tất cả bệnh nhi $\leq 16$ tuổi chẩn đoán sốc sốt xuất huyết dengue tại bệnh viện Nhi Đồng 1 trong thời gian 01/07/2019 đến 30/06/2020. Kết quả: Có 35 bệnh nhi sốc sốt xuất huyết dengue được nhận vào nghiên cứu. Độ tuổi trung bình là $6,8 \pm 3,9$ tuổi, nhóm tuổi $5-10$ tuổi thường gặp nhất. Tỉ lệ Nam/Nữ là $1 / 1,1$. Trẻ béo phì chiếm tỉ lệ $17,1 \%$. Tỉ lệ sốc năng là $17,1 \%$, sốc kéo dài là 2,9\%, tái sốc là 2,9\%. Triệu chứng lâm sàng lúc sốc: gan to $(88,6 \%)$, chấm xuất huyết $(77,1 \%)$, đau bụng $(34,3 \%)$, xuất huyết tiêu hoá $(8,6 \%)$, rối loạn tri giác $(5,8 \%)$, chảy máu nướu răng $(2,9 \%)$. Tỉ lệ suy hô hấp là $40 \%$. $62,8 \%$ bệnh nhân tổn thương gan, $14,3 \%$ suy gan. Tỉ lệ rổi loạn đông máu là 83,9\%. Đông máu nội mạch lan tỏa gặp trong 45,2\% trường hợp. Tổng lượng dịch truyền là 163,5 \pm 43,8 ml/kg với thời gian truyên trung bình là $31,3 \pm 7,9$ giờ. Có $60 \%$ trường hợp cần truyền cao phân tử, $11,4 \%$ truyền chế phẩm máu, 5,7\% truyền albumin. Kết luân: 17,1\% trường hợp sốc nặng, tái sốc và sốc kéo dài là $5,8 \%$. Những biểu hiện lâm sàng thường găp lúc sốc là: gan to, chấm xuất huyết, đau bụng, xuất huyết tiêu hóa. $40 \%$ bệnh nhân suy hô hấp, trong đó có 1 trường hợp thở máy. Tỉ lệ tổn thương gan, rối loạn đông máu khá cao. Có đến $60 \%$ truyền cao phân tử.

Tư khóa: sốc sốt xuất huyết dengue.

\section{SUMMARY}

\section{CHARACTERISTICS OF DENGUE SHOCK SYNDROME IN CHILDREN'S HOSPITAL 1 FROM 2019-2020}

Introduction-Objective: The aim of the study is to determine epidemiological, clinical, subclinical characteristics and treatment of dengue shock syndrome (DSS) were admitted early at Children's Hospital 1.Materials and methods: In this prospective, case-series study, all patients aged $\leq 16$ years with DSS at Children Hospital 1 from 1 from July 1,2019 to June 30,2020 . Results: A total of 35 patients were recruited into our research. The mean age of patients was $6.8 \pm 3.9$ years, the percentage of

${ }^{1}$ Bênhh viện Nhi Đồng 1, Tp. Hồ Chí Minh

${ }^{2}$ Đai hoc Y Dướ Tp. Hồ Chí Minh.

Chịu trách nhiệm chính: Phùng Nguyễn Thế Nguyên

Email: nguyenphung@ump.edu.vn

Ngày nhận bài: 15.9.2021

Ngày phản biên khoa hoc: 5.11 .2021

Ngày duyệt bài: 16.11.2021
Võ Duy Minh¹, Phùng Nguyễn Thế Nguyên ${ }^{1,2}$

$5-10$ age group was highest. Male / female ratio was $1 / 1.1$. The obesity rate was $17.1 \%$. Severe dengue shock rate was $17.1 \%$, prolonged shock rate was $2,9 \%$, recurrent shock rate was $2,9 \%$. Common clinical manifestations were: hepatomegaly $(88.6 \%)$, petechia $(77,1 \%)$, abdominal pain $(34.3 \%)$, gastrointestial bleeding (8.6\%), neurological distubance $(5.8 \%)$, gum bleeding (2.9\%). Respiratory failure rate was $40 \%$. $62.8 \%$ of patients had liver injury, $14.3 \%$ of patients had acute liver failure. Percentage of patients had deranged coagulation profiles was $83.9 \%$. Disseminated intravascular coagulation was found in $45.2 \%$ of cases. The mean total fluid volume was $163,5 \pm 43,8 \mathrm{ml} / \mathrm{kg}$ with mean infusion time was $31,3 \pm 7,9$ hours. Colloid therapy was needed in $60 \%$ of cases, 4 of 35 patients needed infusion of blood products, 2 of 35 patients had albumin infusion. Conclusion: The most common age group was 5 - 10 years. Severe dengue shock rate was $17.1 \%$, recurrent shock and persistent shock wera $5,8 \%$. Common clinical manifestations were: hepatomegaly, petechia, abdominal pain, gastrointestial bleeding, neurological distubance, gum bleeding. The respiratory failure rate was $40 \%, 1$ of whom needed mechanical ventilation. The rate of hepatic damage and abdnomal coagulation profiles were high. Up to $60 \%$ of cases needed colloid therapy.

\section{I. ĐĂT VẤN ĐỀ}

Sốt xuất huyết dengue là bệnh do virus lây truyền từ muỗi gây bệnh cho người quan trọng nhất. Tỉ lệ mới mắc toàn cầu tăng nhiều trong những năm gần đây và những trường hợp nặng càng tăng đặc biệt là sốc. Tỉ lệ tử vong sốt xuất huyết dengue thay đổi từ < $1 \%$ đến $>10 \%$, tùy thuôc nhiều yếu tố như độc lực virus, vật chủ (tuổi, giới, tình trang miễn dịch). Tử vong chủ yếu do sốc và suy cơ quan. Vì vậy, chúng tôi thực hiện nghiên cứu "Khảo sát đặc điểm sốc sốt xuất huyêt dengue tại bệnh viện Nhi Đồng 1" nhằm xác định đặc điểm lâm sàng, cận lâm sàng, biện pháp điều trị sốc sốt xuất huyêt dengue tại bệnh viện Nhi Đồng 1.

\section{II. ĐốI TƯƠNG VÀ PHƯƠNG PHÁP NGHIÊN CỨU}

Thiết kế nghiên cứu. Mô tả hàng loạt ca.

Đối tượng nghiên cứu

Tiêu chuân chọn bệnh: Tất cả bệnh nhi $\leq$ 16 tuổi chẩn đoán sốc sốt xuất huyết dengue nhập viện Bệnh viện Nhi đồng 1 trong thời gian 01/07/2019 - 30/06/2020.

- Thời gian từ lúc sốc đến lúc nhận vào $\leq 12$ giờ.

- Cha me bệnh nhi đồng thuận tham gia

Tiêu chí loai trừ: 
- Có bệnh nền (suy tim, bệnh phổi mạn tính,...)

Các bước tiến hành nghiên cứu. Bệnh nhân sốc sốt xuất huyết dengue được hỏi bệnh sử, thăm khám sau đó điêu trị, theo dõi theo phác đồ. Những đặc điểm lâm sàng, cận lâm sàng, biệp pháp điều trị, kết cục điều trị đến khi xuất viện được thu thập lại.

Xử lý số liệu. Số liệu được xử lý và phân tích bằng phần mềm thống kê SPSS 20.0

Biến số định tính: tính tần số và tỷ lệ.

Biến số định lượng: tính trung bình và độ lệch chuẩn. So sánh tỷ lệ bằng phép kiểm chi bình phương và phép kiểm Fisher, so sánh trung bình bằng t-test, so sánh trung vị bằng phép kiểm Mann-Whitney.

\section{KẾT QUẢ NGHIÊN CỨU}

Từ ngày 01/07/2019 đến 30/6/2020, có 35 trẻ dưới 16 tuổi nhập Bệnh viện Nhi đồng 1 được chẩn đoán sốc sốt xuất huyểt dengue thỏa tiểu chuẩn chọn mẫu được đưa vào nghiên cứu.

\section{Đặc điểm dân số nghiên cứu}

Bảng 1. Đặc điểm dân số nghiên cứu

\begin{tabular}{|c|c|c|c|}
\hline \multicolumn{2}{|c|}{ Đặc điểm dịch tễ học } & $\begin{array}{c}\text { Tần số } \\
(n=35)\end{array}$ & $\begin{array}{l}\text { Tỷ lệ } \\
(\%)\end{array}$ \\
\hline \multirow{4}{*}{$\begin{array}{l}\text { Nhóm } \\
\text { tuổi }\end{array}$} & $\leq 1$ tuối & 3 & 8,6 \\
\hline & $1-5$ tuối & 11 & 31,1 \\
\hline & $5-10$ tuối & 14 & 40 \\
\hline & $>10$ tuối & 7 & 20 \\
\hline \multirow{2}{*}{ Giới } & Nam & 17 & 48,6 \\
\hline & Nữ & 18 & 51,4 \\
\hline \multirow{3}{*}{$\begin{array}{l}\text { Dinh } \\
\text { dưỡng }\end{array}$} & Dư cân & 4 & 11,4 \\
\hline & Béo phì & 6 & 17,1 \\
\hline & $\begin{array}{l}\text { Không dư cân, } \\
\text { béo phì }\end{array}$ & 3 & 8,6 \\
\hline \multirow{2}{*}{$\begin{array}{l}\text { Nơi cư } \\
\text { trú }\end{array}$} & TP.HCM & 23 & 65,7 \\
\hline & Tỉnh thành khác & 12 & 34,3 \\
\hline
\end{tabular}

Đă̆c điểm lâm sàng

Đắc điểm sốc

Bảng 2. Đặc điểm sốc

\begin{tabular}{|c|c|c|c|}
\hline \multicolumn{2}{|c|}{ Đắc điểm } & $\begin{array}{c}\text { Tân số } \\
(\mathbf{n = 3 5 )}\end{array}$ & $\begin{array}{c}\text { Tỉ lê̂ } \\
\mathbf{( \% )}\end{array}$ \\
\hline Mức độn & Sốc & 29 & 82,9 \\
\cline { 2 - 4 } sốc & Sốc nặng & 6 & 17,1 \\
\hline \multirow{3}{*}{$\begin{array}{c}\text { Ngày } \\
\text { vào } \\
\text { sốc }\end{array}$} & 3 & 1 & 2,9 \\
\cline { 2 - 4 } & 4 & 9 & 25,7 \\
\cline { 2 - 4 } & 5 & 20 & 57,1 \\
\hline \multicolumn{2}{|c|}{ Tái sốc } & 5 & 14,3 \\
\hline
\end{tabular}

\begin{tabular}{|c|c|c|c|}
\hline \multicolumn{2}{|c|}{ Sốc kéo dài } & & 2,9 \\
\hline \multicolumn{4}{|c|}{$\begin{array}{l}\text { Triệu chứng lâm sàng } \\
\text { Bảng 3. Triệu chứng lâm sàng }\end{array}$} \\
\hline \multicolumn{2}{|r|}{ Đặc điểm } & $\begin{array}{c}\text { Tân số } \\
(n=35)\end{array}$ & Tỉ lệ \\
\hline \multicolumn{2}{|r|}{ Ói } & 8 & 22,9 \\
\hline \multicolumn{2}{|c|}{ Đau bụng vùng gany } & 12 & 34,3 \\
\hline \multicolumn{2}{|c|}{ Gan to } & 31 & 88,6 \\
\hline \multirow{4}{*}{$\begin{array}{l}\text { Xuất } \\
\text { huyết }\end{array}$} & Chấm xuất huyết & 27 & 77,1 \\
\hline & Chả máu nướu răng & 1 & 2,9 \\
\hline & Xuất huyết tiêu hóa & 3 & 8,6 \\
\hline & Rối loạn tri giác & 2 & 5,8 \\
\hline
\end{tabular}

Đặc điểm cận lâm sàng:

Dung tích hồng câu Dung tích hồng cầu lúc vào sốc của nhóm sốc nặng có trung bình là 47,8 $\pm 4,8 \%$, nhóm sốc là $48 \pm 4,5 \%$, không khác biệt ý nghĩa $(p=0,369)$

\section{Tổn thương cơ quan}

Tổn thương gan: $62,8 \%$ bệnh nhân có tổn thương gan. Trong đó, tổn thương gan nhe chiếm tỉ lệ $40 \%$, tổn thương gan trung bình và nặng bằng nhau với $11,4 \%$. Tỉ lệ suy gan là $14,3 \%$.

Rối loạn đông máu: $83,9 \%$ bệnh nhân rối loạn đông máu trong số 31 trường hợp được xét nghiệm. Trong đó 61,3\% (19 trường hợp) kéo dài $\mathrm{PT}, 87,1 \%$ (27 trường hợp) kéo dài $\mathrm{aPTT}$ và $58,1 \%$ (18 trường hợp) giảm fibrinogen.

Suy hô hấp: Tỉ lệ suy hô hấp là 40\%. Tất cả các trường hợp suy hô hấp đều diễn tiến trong quá trình truyền dịch, không có bệnh nhân nào suy hô hấp ngay từ đầu do nguyên nhân khác như co giật, rối loạn tri giác.

Tràn dịch màng phổi và màng bụng:Tỉ lệ tràn dịch màng phổi là $62,9 \%$, tràn dịch lượng nhiều chiếm $18,2 \%$. Tỉ lệ tràn dịch màng bụng là $62,9 \%$, lượng nhiều chiếm 9,9\%. Có 1 trường hợp tăng áp lực ổ bụng, chiếm 2,9\%, bệnh nhân này là bệnh nhân sốc kéo dài, cần thở máy và được chọc dịch ổ bụng giải áp.

Đăc điểm các biện pháp điêu trị

Loại dịch truyên

Bảng 3. Ti lệ các loại dịch truyền

\begin{tabular}{|c|c|c|}
\hline Đặc điểm & $\begin{array}{c}\text { Tần số } \\
(\mathbf{n = 3 5 )}\end{array}$ & $\begin{array}{c}\text { Tỉ lệ } \\
\mathbf{( \% )}\end{array}$ \\
\hline Chỉ dùng dịch tinh thế & 14 & 40 \\
\hline Có dùng cao phân tữ & 21 & 60 \\
\hline Truyền chế phấm máu & 4 & 11,4 \\
\hline Truyền albumin & 2 & 5,7 \\
\hline
\end{tabular}

Lượng và thời gian truyền

Bảng 4. Lượng dịch và thời gian truyền

\begin{tabular}{|c|c|c|c|}
\hline Đặc điểm & Trung bình $\mathbf{\pm}$ ĐLC & Thời gian (giờ) \\
\hline \multirow{2}{*}{ Tổng dịch } & Eiện giải & $90,5 \pm 57,2$ & $3(1-19)$ \\
\cline { 2 - 4 } & Cao phân tử & $114,4 \pm 40,9$ & $27 \pm 9,8$ \\
\hline Nhóm chỉ dùng tinh thế & $144,5 \pm 25,2$ & $26,2 \pm 5,2$ \\
\hline
\end{tabular}




\begin{tabular}{|c|c|c|c|}
\hline \multirow{2}{*}{$\begin{array}{c}\text { Nhóm có dùng cao phân } \\
\text { tử }\end{array}$} & Dịch tinh thế & $54,6 \pm 41,9$ & $5(1-20)$ \\
\cline { 2 - 4 } & Dịch cao phân tử & $114,4 \pm 40,9$ & $27 \pm 9,8$ \\
\hline
\end{tabular}

Đặc điểm các biện pháp hỗ trợ. Có $74,3 \%$ hỗ trợ hô hấp, trong đó $31,4 \%$ thở NCPAP và $2,9 \%$ thở máy. Giải áp dịch màng bụng có $2,9 \%$ và $2,9 \%$ đo CVP theo dõi điều trị. Đo huyết áp xâm lấn được thực hiện 45,7\% trường hợp. Có $28,6 \%$ dùng lợi tiểu ở giai đoạn tái hấp thu.

\section{BÀN LUẬN}

Độ tuổi trung bình là $6,8 \pm 3,9$. Nhóm tuổi 5 - 9 tuổi chiếm tỉ lệ cao nhất với 45,7\%. Bệnh nhân nhỏ tuổi nhất là 4 tháng tuổi, lớn nhất là 15 tuổi. Tỉ lệ nam/nữ là $1 / 1,1$. Trong 1 nghiên cứu (NC) của đại học Oxford tại TPHCM cho thây nhóm tuổi thường gặp nhất trong sốc SXHD là 6 - 10 tuổi, đồng thời nguy cơ vào sốc cũng cao nhất với OR 1,36 (CI 95\% 1,28 - 1,44). NC này cũng ghi nhận nam chiếm tỉ lệ nhiều hơn nữ nhưng nguy cơ vào sốc của nữ cao hơn với $\mathrm{OR}=1,19$ (95\% CI 1,12 - 1,22)(2). Tương tự, Halstead $S B$ và cs cho thấy nữ chiếm ưu thế hớn trong sốc SXHD độ III, IV và các trường hợp tử vong. Halstead cho rằng đáp ứng miễn dịch ở nữ mạnh hơn nam, dẫn đến cytokine được sản xuất nhiều hơn và có thể thành mao mạch của nữ nhạy cảm hơn với tăng tính thấm thành mạch (2). Tỉ lệ trẻ béo phì trong NC chúng tôi là $17,1 \%$. Tỉ lệ này thấp hơn so với $\mathrm{NC}$ của Văn Thị Cẩm Thanh thực hiện năm 2015 - 2016 tại BV Nhi Đồng 2 với $21,4 \%$, và cao hơn hầu hết các $\mathrm{NC}$ của những năm trước đó. Tỉ lệ trẻ dư cân - béo phì có xu hướng tăng dần qua các năm có thể là do sư thay đổi về măt kinh tế, xã hôi dẫn đên thay đổi về lối sống và dinh dưỡng trẻ em. Khẩu phần ăn càng tăng đạm và béo đồng thời ít vận động hơn ${ }^{(5)}$. $40 \%$ bệnh nhân suy hô hấp. Tỉ lệ bểnh nhân thở oxy và NCPAP lần lượt là $40 \%$ và $31,4 \%$. Có 1 trường hợp thở máy chiếm tỉ lệ $2,9 \%$. Tỉ lệ suy hô hấp trong NC chúng tôi tương tự như NC của 1 số tác giả khác. Tỉ lệ suy hô hấp trong $\mathrm{NC}$ của Lương Anh Tuấn (3) là $41,2 \%$. NC của Huỳnh Nguyễn Duy Liêm ${ }^{(4)}$ ghi nhận tỉ lệ suy hô hấp cần thở oxy canula là $55 \%$, thở NCPAP là $17 \%$. NC của Văn Thi Cẩm Thanh (5) thực hiên trên 322 bênh nhân sốc SXHD tại BV Nhi Đồng 2 ghi nhận tỉ lệ suy hô hấp thấp hơn NC của chúng tôi $(24,8 \%)$. Nguyên nhân có thể do chiến lược truyền dịch khác nhau giữa các bênh viên. Tỉ lê tổn thương gan trong NC của chúng tôi là $62,8 \%$, tổn thương gan nhẹ $40 \%$, tổn thương gan trung bình và nặng bằng nhau với $11,4 \%$. Tỉ lệ suy gan là $14,3 \%$. Có $31 / 35$ trường hợp được xét nghiêm đông máu toàn bô, tỉ lệ rối loạn đông máu là $83,9 \%$. Tỉ lệ DIC là $45,2 \%$. Tỉ lệ tổn thương gan trong NC của Ngô Thi Thanh Thủy(6) là $70 \%$, Văn Thi Cẩm Thanh là $26,9 \%$. NC của Nguyễn Minh Tiến ${ }^{(7)}$ ghi nhânn 14,8\% trường hợp suy gan ở bệnh nhân sốc kéo dài, tỉ lệ này trong $\mathrm{NC}$ của Tạ Văn Trâm là $66 \%{ }^{(8)}$. Sự khác biệt giữa các NC có thể do týp virus lưu hành khác nhau, tiêu chuẩn chẩn đoán suy gan sử dụng trong mối NC cũng khác nhau 1 số điểm.

Bảng 5. So sánh đặc điểm rôi loạn đông máu qua các NC

\begin{tabular}{|c|c|c|c|c|}
\hline Tác giả & aPTT kéo dài (\%) & PT kéo dài (\%) & Fibrinogen giảm (\%) & DIC (\%) \\
\hline Tạ Văn Trầm & 77,5 & 61,2 & 92,5 & 73,8 \\
\hline Nguyền Minh Tiến & 76,4 & 69,8 & 89 & 84,6 \\
\hline Chúng tôi & 87,1 & 61,3 & 58,1 & 45,2 \\
\hline
\end{tabular}

NC của Tạ Văn Trầm và Nguyễn Minh Tiến thực hiện trên bệnh nhân sốc kéo dài nên tỉ lệ DIC cao hơn. Phải chăng tỷ lệ sốc kéo dài giảm, DIC giảm; có sự góp phần của dịch cao phân tử cần được nghiên cứu thêm. Tổng lượng dịch truyền trong NC chúng tôi là $163,5 \pm 43,8 \mathrm{ml} / \mathrm{kg}$, trong đó lượng dịch tinh thể và cao phân tử lần

lượt là $90,5 \pm 57,2 \mathrm{ml} / \mathrm{kg}$ và $114,4 \pm 40,9 \mathrm{ml} / \mathrm{kg}$. Tổng thời gian truyền dịch có trung bình là 31,3 $\pm 7,9$ giờ. Dịch cao phân tử được sử dụng là HES 200/0,5 6\%, tỉ lệ bệnh nhân cần truyền cao phân tử là $60 \%$. Tỉ lệ truyền chế phẩm máu và truyền albumin lần lượt là $11,4 \%$ và $5,7 \%$.

Bảng 6. So sánh đặc điểm dịch truyền qua các NC

\begin{tabular}{|c|c|c|c|c|}
\hline Tác giả & $\begin{array}{l}\text { Tỉ lế dùng } \\
\text { CPT (\%) }\end{array}$ & $\begin{array}{l}\text { Lương dịch tinh } \\
\text { thể }(\mathrm{m} / \mathrm{kg})\end{array}$ & $\begin{array}{l}\text { Lượng dịch } \\
\text { CPT (ml/kg) }\end{array}$ & $\begin{array}{l}\text { Tống lương dịch } \\
\text { truyền }(\mathrm{ml} / \mathrm{kg})\end{array}$ \\
\hline Cao Thi Tố Như & & $63,5 \pm 38,7$ & $72,9 \pm 40,3$ & $188,4 \pm 40,5$ \\
\hline Văn Thi Cấm Thanh & 52,5 & $70,6 \pm 34,2$ & $86,2 \pm 56,3$ & $115,9 \pm 44,8$ \\
\hline Chúng tôi & 60 & $90,5 \pm 57,2$ & $114,4 \pm 40,9$ & $163,5 \pm 43,8$ \\
\hline
\end{tabular}

Lượng dịch truyền khác nhau có thể do chiến cũng có thể do tỉ lệ bệnh nhân sốc kéo dài, tái lược truyền dịch ở mỗi bệnh viện khác nhau, sốc khác nhau. Trải qua rất nhiều hướng dẫn 
điều trị, trong việc nổ lực giảm tỷ lệ dịch truyền ở bệnh nhân sốc sốt xuất huyết dengue, nhưng lượng dịch cũng không giảm, điều đó cho thây sinh bệnh học của sốt xuất huyết dengue là tình trạng thoát huyết tương, và việc bù dịch điều trị là vô cùng quan trọng.

\section{KẾT LUÂN}

Trẻ sốc sốt xuất huyết dengue nhập bệnh viện nhi đồng 1 từ sớm vẫn có tỷ lệ tổn thươnng cớ quan cao và tổng lượng dịch truyền của trẻ cũng còn rất nhiều.

\section{TÀI LIÊU THAM KHẢO}

1. World Health Organization, Research Special Programme for, Diseases Training in Tropical, et al. (2009), Dengue: guidelines for diagnosis, treatment, prevention and control, World Health Organization,Bộ Y tế (2019), "Hướng dẫn chẩn đoán, điều trị sốt xuất huyết dengue", Hà Nội.

2. Halstead S. B. (1988), "Pathogenesis of dengue: challenges to molecular biology", Science, 239(4839), pp. 476-81.
3. Lương Anh Tuấn (2007), Mối liên quan giữa tình trạng béo phì với đặc điêm lâm sàng và điều trị trong sốc sốt xuất huyết dengue ở trẻ từ 2 đến 15 tuổi, Luận văn Bác sĩ chuyên khoa cấp II, Đại học Y dước TंP. Hồ Chí Minh.

4. Huỳnh Nguyễn Duy Liêm (2009), Đặc điểm dịch tễ, lâm sàng, cân lâm sàng và điêu trị ở trẻ em bi sốc sốt xuất huyết có rối loan đông máu, Luân văn Thạc sĩ Y học, Đai học Y dược TP. Hồ Chí Minh.

5. Văn Thi Cẩm Thanh (2017), Đăc điểm dich tễ, lâm sàng, cận lâm sàng và điều trị bệnh nhân sốt xuất huyết dengue nặng có sốc tại bệnh viện Nhi đồng 2. Luân văn thac sĩ y hoc, Đai học Y dước TPHCM.

6. Ngô Thị Thanh Thừy (2010), Đặc điểm rối loạn chức năng gan và rối loạn đông máu trên bệnh nhân sốt xuất huyết dengue điều trị tai bệnh viện Nhi đồng 2, Luận văn tốt nghiệp Bác sĩ nội trú, Đại học Y dược TP. Hồ Chí Minh.

7. Nguyển Minh Tiến (2005), Tổn thương các cơ quan trong sốc sốt xuất huyết Dengue kéo dài ở trẻ em, Luâan án Bác sỹ chuyên khoa II, Đại học Y dược TP Hồ Chí Minh.

8. Tạ Văn Trâm, Hoàng Trong Kim và Nguyễn Trọng Lân (2003), "Các yểu tố liên quan đến sốc sốt xuất huyết Dengue kéo dài ở trẻ em", Tạp chí Nhi khoa, 11(1), tr. 64-70.

\title{
PHẪU THUẬT U XƠ MACH VÒM MŨI HỌNG XÂM LẤN VÙNG XOANG HANG VÀ NộI Sọ
}

\author{
Trần Hạnh Uyên*, Nguyễn Thị Phương Lam*, Lê Thị Anh Thu*,
} Nguyễn Ngọc Khang*, Trần Minh Trường*

\section{TÓM TẮT}

Mục tiêu: Báo cáo hôi cứu và phân tích dấu hiêu về lâm sàng, hình ảnh học, kết quả điều trị của JNA xâm lấn vào trong sọ. Đường đi của u khi xâm lấn vào sọ, tần suất bệnh xầm lấn vào sọ và ảnh hưởng của các biện pháp điều trị được bàn luận. Đối tượng và phương pháp nghiến cứu: Trong nghiên cứu này chúng tôi hồi cứu 5 ca bệnh JNA xâm lấn vào nội so tuổi từ 13 đến 28. trong thời gian từ 2018-2021. Kết quả: Theo phân loại của Session 5 bênh nhân được phân loại giai đoạn III, xâm lấn vào trong sọ là 2 ca và ngoài sọ vừng xoang hang là $3 \mathrm{ca}$. Tất cả bệnh nhân được phẫu thuật cắt $u$ và thực hiện qua đường Degloving "lột găng" và Trước tai dưới hố thái dương hoặc phối hợp. Nội soi được sự dụng hố trợ khi cần thiết. Thời gian theo dõi sau phẫu thuật là 2 năm. Kết luận: U có thể phát triển xâm lấn vào sọ qua các khe hoặc lỗ tự nhiên để vào phía trong vùng nền sọ đăc biệt là vị trí khe ổ mắt trên. Do nguy cơ phẫu thuật, tái phát và biến chứng nên các khối u lan rộng cần được điều trị bởi kíp các bác sĩ nhiều chuyên khoa với

*Bệnh viện Chợ Rẫy

Chịu trách nhiệm chính: Trân Hạnh Uyên

Email: uyenent@gmail.com

Ngày nhận bài: 14.9.2021

Ngày phản biên khoa học: 4.11 .2021

Ngày duyệt bài: 15.11.2021 các kỹ thuật và phương tiện điều trị hiện đại và thích hợp.

\section{SUMMARY \\ SURGICAL APPROACH FOR JUVENILE ANGIOFIBROMA WITH INTRACRANIAL EXTENSION}

Introduction: Middle skull base and infratemporal fossa are the most complex anatomical structure and difficult to approach. Tumors in this area are very diverse, located close to other critical neurovascular structures, therefore, surgical approach to remove tumors is always a challenge. Objective: The article review clinical symptoms, radiological images and outcomes of surgical approach to remove JNA tumors with middle cranial fossa and cavernous sinus extension. Pathway for tumor invade the the middle cranial fossa and its incidence at otorhinolaryngology department of Cho Ray hospital. Methods: The study is a case series to review 05 patients (ages 13 to 28) diagnosed with JNA tumor with intracranial extension from 2018 - 2021. Results: All 5 patients with JNA was diagnosed with stage III. All of them were treated with Degloving approach and Preauricular Subtemporal Infratemporal Fossa approach or combining those techniques. Endoscopic surgery was used as additional technique. Follow up was 2 years. Conclusion: Tumor can invade middle cranial fossa and cavernous sinus through natural fissure and 